\title{
Management of Vietnamese Civil Servants Research: A Descriptive Approach
}

\author{
Nguyen Thi Thu Hương \\ Academy of Finance, 58 Le Van Hien Street, Duc Thang Ward, \\ Bac Tu Liem District, Hanoi 100000, Vietnam
}

Received: Feb. 4, 2021 Accepted: Mar. 5, 2021 Online published: Mar. 17, 2021

doi:10.5296/jpag.v11i1.18427～URL: https://doi.org/10.5296/jpag.v11i1.18427

\begin{abstract}
In the administration of any country, civil servants always hold a particularly important position. The quality of administrative civil servants directly affects the performance quality of the Government apparatus from central to grassroots levels. The effectiveness and efficiency of Government management are always a direct result from the performance of administrative civil servants. Therefore, building, consolidating and improving the contingent of civil servants to meet the requirements of the current international economic integration is both the goal and the driving force to promote the Vietnamese administrative research in Dien Bien District, Dien Bien province, pointed out the results achieved, the limitation and reasons for management of Vietnamese civil servants, and then proposed some recommendations to improve the management of Vietnamese civil servants in the context of international economic integration.
\end{abstract}

Keywords: management, civil servant, Vietnam

\section{Introduction}

In reality, the operation of the state administrative apparatus in Dien Bien province in general and in Dien Bien district in particular, shows that: Civil servants in state agencies perform all activities of state administrative organizations, is core human resource in management and implementation of the functions and tasks of State administrative agencies. They mainly perform the task of advising and making policies, executing, monitoring and examining law enforcement. Thanks to that, the state administrative apparatus can fulfill its functions and tasks, manage all activities of the society in general and the agency in particular, always in a stable and orderly state. And in the direction of development.

However, the contingent of civil servants in Dien Bien province in general and Dien Bien district in particular still has limitations and weaknesses: the functions, duties and standards 
of each public servant have not been defined yet. state Administration; The situation of both redundancy and lack of civil servants is still quite common; The qualifications of the contingent of civil servants in general are not highly specialized, the main administrative skills, the capacity to synthesize, analyze and propose issues on institutions, mechanisms and policies are still limited. The function of using foreign languages, information technology, including management officials at all levels is still poor. Inadequacies in the recruitment, use and treatment of civil servants are slow to be resolved; bureaucracy, harassment, arrogance, corruption, and waste in a part of civil servants in public service have not been pushed back, undermining the confidence of a significant part of the people in the public office affecting the reputation of the Party Committee of Dien Bien Province and the local government. Stemming from the above practice, the author wants to share his opinion and propose a number of recommendations with scientific and practical basis on this issue. The author mainly uses descriptive statistical methods to analyze reality, results and limit the situation of civil servant management in Dien Bien District, Dien Bien Province, Vietnam.

\section{Literature Review}

According to the Law on Cadres and Civil Servants, public service activities of cadres and civil servants are to perform their duties and powers in accordance with the law. They are implemented with the following principles: Compliance with the Constitution and laws: All civil service activities of public officials and employees must comply with the law because public service is an obligation of the state; Protection of the interests of the State, the legitimate rights and interests of organizations and citizens: Public service activities must serve the interests of the State and protect the legitimate rights and interests of organizations and citizens. While on duty, cadres and civil servants must serve the people and listen to their opinions; Publicity, transparency, right authority and subject to inspection and supervision: Public service activities must be performed publicly by authorized persons and subject to the inspection and supervision of competent agencies. Decisions and behavior of cadres and civil servants must be clear, transparent and in accordance with the law; Ensure the systematic, synchronous, continuous, smooth and efficient. Due to the systematic nature, public service activities are only effective if they are carried out continuously, consistently and uninterrupted from high to low level; Ensuring the administrative decentralization system and close coordination. In the administrative hierarchy, the subordinates must submit to the superiors and the local government must submit to the central government. Administrative decentralization must go hand in hand with close coordination between levels, sectors, cadres and civil servants holding different positions and powers in public service (Diem, 2012).

Tan (2018) said that activities of cadres, civil servants and public employees of the state apparatus, political organizations, socio-political organizations and many other social organizations, to the village quality are for the public interest. This stems from the state nature of the people, by the people, for the people and for the common goal of the political system. The Law on Cadres and Civil Servants in 2008 states: "Officials of cadres and civil servants are the performance of duties and powers of cadres and civil servants defined by this Law and other relevant regulations". It is impossible to prescribe the right number of civil servants per capita, given the differences in their functions, and in the number of intrastate 
governmental levels in different states. In economically developed states, the tendency is to cut down the scope of civil service activities (and consequently its size as well) through privatization, outsourcing, and delegation of responsibilities to nonprofit civil society organizations. In new areas, the pressure still exists on the civil service to do much more for their hard-pressed societies (Itzhak Galnoor, Jennifer Oser, 2015).

According to PJ ACAD (2020), the civil servants by virtue of their knowledge, experience, and understanding of public affairs assist the ministers in formulating policy and are responsible for implementing these policies wherein ministers are accountable to parliament and civil servants are accountable to ministers. Though we are a democracy and power is vested in the people, neither politicians nor civil servants are directly and meaningfully accountable to the public. Each civil servant, in addition to the criteria of general quality and capacity, also has special and special abilities, capacities, elites, talents, and even "outstanding" capacities. tendencies to lead, manage, operate professionally, so the labor organizer must arrange, arrange people, and look at people to assign jobs; for the job requirements of agencies and organizations to build structure, payroll, select and use cadres and civil servants. Not for negative reasons in the organization and personnel work; for the personal needs and interests of civil servants to give birth to organizations and work arrangements (Thang, 2018).

Duong (2019) commented that in fact, the contingent of cadres and civil servants working in ministries, branches and specialized agencies of the People's Committee has gradually been raised in terms of professional qualifications, quality and work efficiency. The training and retraining of cadres, civil servants and public employees have been interested in by ministries, branches and localities according to annual plans. The organization of rank promotion examinations for the contingent of civil servants and public employees is carried out more frequently; Thereby, the number of senior experts, main experts working in ministries, branches and specialized agencies under the provincial People's Committee has been increased. Personnel organization, recruitment, appointment, planning, promotion and rotation of cadres and civil servants in accordance with their professional qualifications, training skills and working skills are concerned, attaching importance to renovating the structure of the contingent of cadres, civil servants and public employees. However, the management of staff is still limited. In the previous period, the number of officials who violated the law also existed but not much, the impact was not serious. Currently, there is almost no branch and locality do not have a part of officials working irresponsibly to the Party, the State, and the people. Especially bad corruption and wastefulness of many officials have become the most pressing problem in society. State enterprise management, land management, minerals, basic construction, public property management, etc. have caused great losses and damages to the state budget. The management of cadres in a few agencies of inspection, examination, investigation, prosecution and adjudication are not good, therefore, there are some unfortunate cases (Trung, 2018).

Long (2020) said that in order to overcome the limitations and weaknesses in the assessment of cadres, civil servants and public employees mentioned above, the Law has added regulations on the evaluation of cadres, civil servants and public employees by specific 
criteria, by product; associating individual assessment with the collective and results of implementing the tasks of localities, agencies and units. However, the contingent of civil servants and public employees in our country working in very wide fields with different characteristics depends on each job and region. Therefore, the Law also stipulates that the heads of competent agencies to manage civil servants are assigned in accordance with their locality, ministry or branch, ensuring the set criteria. In the task of organizing the recruitment of cadres and civil servants as well as all cadres and civil servants who are planned to be leaders and managers, it is necessary to assign a unit independent from the locality to manage and use cadres and public servants to organize entrance examination. Assigning an independent unit to organize the recruitment is really objective, fair, democratic, avoiding local local situation. The Party and State need to have a more specific mechanism, strictly handle leading officials and manage so that their relatives and family members do not meet the standards to participate in the leadership and management apparatus. In the assessment of cadres and civil servants every year, each agency or unit should have a set of criteria and standards to be evaluated to suit the job position, avoiding the case of using a set of criteria that the establishment evaluates. For each job of an officer, a civil servant will not be evaluated comprehensively (Quyen, 2020).

\section{Method}

Data collected and aggregated from the Department of Organization and Home Affairs of Dien Bien district from 2015 to 2019, reports on the quality of cadres and civil servants from 2015-2019 by the People's Committee of Dien Bien district, Plan on payroll of civil servants at the specialized agencies of the People's Committee of Dien Bien district from 2015 to 2019.

\section{The Management of Civil Servants in Dien Bien District, Dien Bien Province, Vietnam}

\subsection{An Overview of Dien Bien District and the People's Committee of Dien Bien District}

\section{An overview of Dien Bien District}

Dien Bien district, which was established on October 27, 1962, is a border district located in the southwest of Dien Bien province, the North borders Muong Cha district, the East borders Dien Bien Dong district, the Northeast borders Dien Bien Phu city, the West and South borders the Lao People's Democratic Republic.

Natural area is 139,595.93 ha (of which: 122,562.46 ha of agricultural land, 4,255.68 ha of non-agricultural land, 12,687.80 ha of unused land); 171,205 km of national border with two northern provinces of Laos, 61 national border markers and quota roads, with two border gates (Tay Trang international border gate, Huoi Puoc National border gate).

The district has 21 communal administrative units (of which: 12 communes in the basin, 12 border communes). Population of over 100 thousand people, including 07 living ethnic groups: Thai ethnic group 52.89\%, Kinh ethnic group 27.03\%, Mong people 9.96\%, Kho Mu ethnicity $5.58 \%$, Lao people $2.84 \%$, the rest are from other ethnic groups. 
As a district with complicated terrain, difficult transportation, pure agricultural economy is slow to develop; The level of people's knowledge is low and uneven, the awareness of development and the sense of self-improvement to escape poverty of a part of the people is still limited, while there are thoughts of counting on the State's support; free migration, abuse of religious beliefs, illegal trafficking in and use of drugs. There are many complicated and unpredictable developments that have significantly affected the lives of ethnic groups in the district and the district's socio-economic development.

In recent years, with the attention of the government, all levels and branches in the province, the striving efforts of the Party Committee, the government, the army and people of the ethnic groups in the district, the material life The quality and spirit of the people of ethnic groups in the district has been gradually improved, the national border sovereignty, political security and social order and safety of the district have been basically maintained and stable; The political system from district to grassroots continues to be consolidated, consolidated, to meet the requirements of serving local political tasks.

\section{Organizational structure of the People's Committee of Dien Bien district}

Pursuant to the Government's Decree No. 37/2014/ND-CP, dated May 5, 2014, defining the organization of specialized agencies under the People's Committees of districts, urban districts, towns and provincial cities; Dien Bien District People's Committee includes 13 specialized agencies including: Office of People's Council and District People's Committee; Organizing Committee and Interior; Inspection Committee - Inspection; Division of Agriculture and Rural Development; Department of Economy and Infrastructure; Financial planning office; Resources and Environmental office; Judicial departments; Education and training room; Office of Culture and Information; District Labor - Invalids and Social Affairs Division; Public health station and Ethnic Room.

\subsection{The Contingent of Civil Servants at Specialized Agencies of the People's Committee of} Dien Bien District

In terms of quantity, structure of civil servants

To perform the state management function in the district, based on the working positions of civil servants, the Provincial People's Committee annually assigns the payrolls of civil servants to the district People's Committee, the district People's Committee assigns payroll to specialized agencies under the People's Committee District. The number of payrolls of the District People's Committee from 2015 to December 31, 2019 is specifically allocated through Table 1:

Table 1. Number and structure of civil servants at the specialized agencies of the People's Committee of Dien Bien district

\begin{tabular}{|l|l|c|c|c|c|c|}
\hline No. & Classification & $\begin{array}{c}\text { Year } \\
2015\end{array}$ & $\begin{array}{c}\text { Year } \\
2016\end{array}$ & $\begin{array}{c}\text { Year } \\
2017\end{array}$ & $\begin{array}{c}\text { Year } \\
2018\end{array}$ & $\begin{array}{c}\text { Year } \\
2019\end{array}$ \\
\hline \multicolumn{2}{|l|}{ Total number of people: } & 117 & 117 & 112 & 110 & 95 \\
\hline
\end{tabular}




\begin{tabular}{|c|c|c|c|c|c|c|}
\hline \multirow[t]{3}{*}{1} & Male/ female structure & & & & & \\
\hline & - Male (\%): & $52.8 \%$ & $53.3 \%$ & $55.9 \%$ & $57.1 \%$ & $59.3 \%$ \\
\hline & - Female (\%): & $47.2 \%$ & $46.7 \%$ & $44.1 \%$ & $42.9 \%$ & $40.7 \%$ \\
\hline \multirow[t]{5}{*}{2} & Structure by industry/level & & & & & \\
\hline & - Main experts (\%) & $4.7 \%$ & $4.7 \%$ & $3.6 \%$ & $3.8 \%$ & $3.9 \%$ \\
\hline & - Expert (\%) & $74.6 \%$ & $75.9 \%$ & $80 \%$ & $81.5 \%$ & $87.4 \%$ \\
\hline & - Technician (\%) & $19.8 \%$ & $18.5 \%$ & $15.5 \%$ & $13.5 \%$ & $6.6 \%$ \\
\hline & - Agent (\%) & $0.9 \%$ & $0.9 \%$ & $0.9 \%$ & $1.2 \%$ & $2.1 \%$ \\
\hline 3 & Structure by age & & & & & \\
\hline & - 30 or less $(\%)$ & $26.5 \%$ & $26.1 \%$ & $23.8 \%$ & $20.0 \%$ & $17.6 \%$ \\
\hline & - From 31 to $40(\%)$ & $27.4 \%$ & $28 \%$ & $33.0 \%$ & $44.3 \%$ & $46.1 \%$ \\
\hline & - From 41 to $50(\%)$ & $32 \%$ & $27.2 \%$ & $25.6 \%$ & $17.2 \%$ & $16.4 \%$ \\
\hline & - Over $51(\%)$ & $4.1 \%$ & $18.7 \%$ & $17.6 \%$ & $18.5 \%$ & $19.9 \%$ \\
\hline \multirow[t]{3}{*}{4} & Structure by ethnic group & & & & & \\
\hline & - $\quad$ Kinh (\%) & $68 \%$ & $69 \%$ & $66.1 \%$ & $69.9 \%$ & $71.5 \%$ \\
\hline & - Ethnic minority (\%) & $32 \%$ & $31 \%$ & $33.9 \%$ & $30.1 \%$ & $28.5 \%$ \\
\hline 5 & The proportion of party members & $66 \%$ & $66.9 \%$ & $61.4 \%$ & $70.3 \%$ & $71.4 \%$ \\
\hline
\end{tabular}

(Source: Dien Bien District's Organizing Committee and Interior Statistics in December 2015, 2016, 2017, 2018, 2019)

Table 1 shows:

- Regarding the gender structure as of 2019: Female civil servants account for $40.7 \%$ of the total number of civil servants under the District People's Committee. This shows that the male/female ratio is still unbalanced;

- Regarding the civil servant category as of 2019: The proportion of civil servants holding the rank of main specialist remains low, accounting for only $3.9 \%$; the proportion of holding specialist ranks has increased from $74.6 \%$ in 2015 to $87.42 \%$ in 2019 ; the rate of holding the rank of personnel decreased sharply from $19.8 \%$ in 2015 to $6.6 \%$ in 2019; employee turnover increased from $0.9 \%$ in 2015 to $2.1 \%$ in 2019.

- In terms of age structure, there has also been progress in the rejuvenated ages.

- Regarding the ethnic composition structure: Civil servants who are ethnic minorities, accounting for $28.5 \%$ of the total number of civil servants under the District People's Committee, tend to decrease from $32 \%$ in 2015 to $28.5 \%$ in 2019.

- Percentage of civil servants being party members accounts for $71.4 \%$ of the total number of civil servants of the district People's Committee. 
Over the past years, the District People's Committee has paid attention to developing new party members, basically meeting the requirements, but in order to improve leadership capacity and fighting strength of Party organizations, Dien Bien District People's Committee. It is necessary to continue to pay more attention in developing new party members to supplement and strengthen the party member force for Party grassroots organizations in specialized agencies of the District People's Committee to promote and maintain the leadership role of the party religion in state administrative organs.

The proportion of civil servants who are women and ethnic minorities out of the total number of civil servants under the District People's Committee is relatively appropriate and balanced. However, due to the area of a mountainous, border district, the population is ethnic minority majority, the increase in the proportion of civil servants who are women, who are ethnic minorities in specialized agencies under the district People's Committee has It is of particular importance to the implementation of the Party's ethnic policies and gender equality policies. Therefore, in the coming years, Dien Bien District People's Committee should continue to pay attention and adopt policies to train and foster, prioritize the recruitment of female civil servants, who are ethnic minorities to well implement the law on gender equality and the Party's ethnic policy.

\section{About the quality of civil servants}

The quality of civil servants at specialized agencies of the district from 2015 to December 31, 2019 is specifically allocated in Table 2 :

Table 2. Quality of formulations at specialized agencies of the People's Committee of Dien Bien district

\begin{tabular}{|c|c|c|c|c|c|c|c|c|c|c|c|}
\hline \multirow[t]{2}{*}{ No. } & \multirow[t]{2}{*}{ Types } & \multicolumn{2}{|c|}{2015} & \multicolumn{2}{|c|}{2016} & \multicolumn{2}{|c|}{2017} & \multicolumn{2}{|c|}{2018} & \multicolumn{2}{|c|}{2019} \\
\hline & & 117 & $\begin{array}{l}\text { Ratio } \\
\%\end{array}$ & 117 & $\begin{array}{l}\text { Ratio } \\
\%\end{array}$ & 112 & $\begin{array}{c}\text { Ratio } \\
\%\end{array}$ & 110 & $\begin{array}{c}\text { Ratio } \\
\%\end{array}$ & $\begin{array}{l}9 \\
5\end{array}$ & $\begin{array}{l}\text { Ratio } \\
\%\end{array}$ \\
\hline \multirow[t]{5}{*}{1} & Qualification: & & & & & & & & & & \\
\hline & - Masters & 2 & 1.7 & 2 & 1.7 & 3 & 2.7 & 4 & 3.6 & 6 & 6.3 \\
\hline & - University & 85 & 72.6 & 84 & 72.6 & 96 & 85.7 & 90 & 81.7 & $\begin{array}{l}7 \\
7\end{array}$ & 81.1 \\
\hline & - Colleges & 8 & 6.8 & 8 & 6.8 & 3 & 2.7 & 4 & 3.6 & 3 & 3.1 \\
\hline & - Intermediate & 22 & 18.9 & 22 & 18.9 & 10 & 8.9 & 12 & 11.0 & 9 & 9.5 \\
\hline \multirow[t]{3}{*}{2} & Political theory level: & & & & & & & & & & \\
\hline & $\begin{array}{l}\text { - Bachelor's degree, } \\
\text { senior }\end{array}$ & 13 & 11.1 & 15 & 12.8 & 18 & 16.1 & 15 & 13.6 & $\begin{array}{l}1 \\
6\end{array}$ & 16.8 \\
\hline & - Intermediate & 14 & 11.9 & 14 & 11.9 & 18 & 16.1 & 24 & 21.9 & $\begin{array}{l}2 \\
7\end{array}$ & 28.4 \\
\hline
\end{tabular}




\begin{tabular}{|c|c|c|c|c|c|c|c|c|c|c|c|}
\hline 3 & $\begin{array}{l}\text { State management } \\
\text { qualifications: }\end{array}$ & & & & & & & & & & \\
\hline & - Main experts & 7 & 6.0 & 6 & 5.2 & 13 & 11.6 & 13 & 11.8 & 1 & 12.6 \\
\hline & - Expert & 53 & 45.3 & 61 & 52.1 & 68 & 60.7 & 61 & 55.4 & $\begin{array}{l}5 \\
7\end{array}$ & 60.0 \\
\hline 4 & English level: & & & & & & & & & & \\
\hline & $\begin{array}{l}\text { - Intermediate and } \\
\text { up }\end{array}$ & 3 & 2.6 & 3 & 2.6 & 3 & 2.7 & 3 & 2.7 & 4 & 4.2 \\
\hline & - Certificate & 58 & 49.6 & 64 & 54.7 & 64 & 57.1 & 60 & 54.5 & $\begin{array}{l}5 \\
7\end{array}$ & 60.0 \\
\hline 5 & Computer skill: & & & & & & & & & & \\
\hline & $\begin{array}{l}\text { - Intermediate and } \\
\text { up }\end{array}$ & 3 & 2.6 & 3 & 2.6 & 3 & 2.7 & 3 & 2.7 & 2 & 2.1 \\
\hline & - Certificate & 82 & 70.0 & 96 & 82.0 & 96 & 85.7 & 87 & 79.0 & 8 & 85.3 \\
\hline
\end{tabular}

(Source of reports on the quality of cadres and civil servants from 2015 to 2019 by the People's Committee of Dien Bien district)

\section{Professional qualifications}

Qualification Civil servants with professional qualifications: Master, in 2015 there are two people, accounting for $1.7 \%$ in 2019 , there are six people, accounting for $6.3 \%$; Professional University, in 2015 there were 85 people, accounting for $72.6 \%$ by 2019 there were 77 people, accounting for $81.1 \%$; Professional College, in 2015 there were 08 people, accounting for $6.8 \%$ by 2019 , and 03 people, accounting for $3.1 \%$; Professional Intermediate 2015 with 22 people accounting for $18.9 \%$ by 2019 and nine people accounting for $9.5 \%$. Civil servants under the People's Committee of Dien Bien district basically meet the standard qualifications required by the job position, but the number of civil servants with postgraduate qualifications is very few, no civil servant has advanced professional qualifications and up. This is a major obstacle for the district's development policy making in the period of accelerating industrialization, modernization and international integration, requiring the People's Committee of Dien Bien district to have special policies in training and retraining for civil servants under the District People's Committee in the coming time.

\section{About the level of political reasoning}

Civil servants with political theory qualifications: Bachelor and senior in 2015 are 13 people, accounting for $11.1 \%$ by 2019, 16 people, accounting for $16.8 \%$. Civil servants with intermediate level of political theory: In 2015, 14 people, accounting for 11.9\%, by 2019, 27 people, accounting for $28.4 \%$. Although civil servants of the district People's Committee have been interested in sending political theory training by the District People's Committee, the 
proportion of civil servants under the district People's Committee with high-level political theory is still very few, reaching 16.8.\% (2019) over the total number of civil servants of the district People's Committee. Therefore, Dien Bien District People's Committee needs to pay attention to well implement the development of plans and plans to send civil servants to attend training courses on political theory - administrative with high level and bachelor's degree to avoid the inadequacy of political - administrative theoretical level in the next few years.

\section{State management qualifications}

Civil servants who have obtained certificates of fostering in state management knowledge to senior specialists and equivalent: None; civil servants who have obtained certificates of fostering knowledge of state management, major specialist rank and equivalent: In 2015 there are 07 people, accounting for $6.0 \%$ by 2019, there are 12 people, accounting for $12.6 \%$ of the total number of public employees District People's Committee; civil servants who have had certificates of fostering knowledge of state management specialist rank and equivalent to 2019 is 57 people, accounting for $60.0 \%$ of the total number of civil servants under the district People's Committee.

Regarding foreign language and computer skills:

- Foreign Language:

Civil servants with Intermediate language level: In 2015, there were three people, accounting for $2.6 \%$, in 2019 there were four people, accounting for $4.2 \%$.

Civil servants with foreign language certificates at level A, B, C: 58 people in 2015, accounting for $49.6 \%$ by 2019,57 people, accounting for $60.0 \%$ of the total number of civil servants under the district People's Committee.

- Information Technology:

Public servants with degrees from University of Information Technology: No.

Civil servants with Intermediate level of Information Technology: By 2019, there are two people, accounting for $2.1 \%$ of the total number of civil servants under the District People's Committee.

Civil servants with certificates of IT at levels A, B, C: 82 people in 2015, accounting for $70.0 \%$ by 2019,81 people, accounting for $85.3 \%$ of the total number of civil servants under the district People's Committee.

Over the past years, Dien Bien District People's Committee has been interested in training and retraining to improve foreign language and computer skills for civil servants of the district People's Committee, but the number of civil servants with foreign language and computer skills from Intermediate and above. Up to now, it has not increased, so it will be difficult to meet the requirements in implementing the district e-Government program, this is an issue that Dien Bien District People's Committee needs to pay attention to, adopt policies and plans. plans to send civil servants to training to improve their computer skills and foreign 
languages to meet the computerization requirements of the district People's Committee in the coming years.

\subsection{Construction Status of the Scheme of Employment Positions and Civil Servant Category Structure in the Locality}

Annually, based on the current documents of the province defining the functions, tasks, powers, organizational structure of specialized divisions and departments of the district People's Committee; list of job positions; civil servant criteria and titles corresponding to job positions; the nature, characteristics and job requirements of each agency; complexity, scale of work; scope and object to serve, manage; management processes and procedures and performance of professional tasks; level of modernization of offices, equipment, working facilities and application of information technology in management activities and status of the arrangement and use of civil servants of specialized agencies under the District People's Committee. The District People's Committee has instructed specialized agencies to develop projects of job positions and civil servant ranks according to regulations, consistent with the general situation of the district and functions and tasks assigned to the district People's Committee for appraisal to synthesize and submit to the Department of Home Affairs for appraisal, submit to the Provincial People's Committee for approval and strictly implement the contents of the approved project.

Job position schemes include full content, including the criteria related to civil servants and suitable to the functions, tasks, powers and organizational structure of each agency, specifically in Table 3:

Table 3. Construction status of job placement projects in specialized agencies of Dien Bien District People's Committee in the period 2015-2019

\begin{tabular}{|c|c|c|c|}
\hline Step & Project construction work & Implementing agencies & Obtained product \\
\hline 1 & $\begin{array}{l}\text { Personal work statistics; } \\
\text { Work statistics of agencies } \\
\text { and organizations }\end{array}$ & $\begin{array}{l}\text { Civil servants of } 13 \text { specialized } \\
\text { divisions of Dien Bien District } \\
\text { People's Committee }\end{array}$ & $\begin{array}{l}\text { The work statistics of civil } \\
\text { servants }\end{array}$ \\
\hline 2 & Grouping of work & $\begin{array}{l}\text { Heads of } 13 \text { specialized } \\
\text { divisions of Dien Bien District } \\
\text { People's Committee }\end{array}$ & $\begin{array}{l}\text { Summary of the work of } 13 \\
\text { professional departments }\end{array}$ \\
\hline 3 & $\begin{array}{l}\text { Determine the factors that } \\
\text { influence the job }\end{array}$ & $\begin{array}{l}\text { Heads of } 13 \text { specialized } \\
\text { divisions of Dien Bien District } \\
\text { People's Committee }\end{array}$ & $\begin{array}{l}13 \text { copies of factors affecting } \\
\text { the work of } 13 \text { departments }\end{array}$ \\
\hline 4 & $\begin{array}{l}\text { Statistics and assessment of } \\
\text { the current state of the } \\
\text { contingent of civil servants }\end{array}$ & $\begin{array}{l}\text { Heads of } 13 \text { specialized } \\
\text { divisions of Dien Bien District } \\
\text { People's Committee }\end{array}$ & $\begin{array}{l}\text { The list of } 13 \text { departmental } \\
\text { civil servants }\end{array}$ \\
\hline 5 & category & Heads of 13 specialized & List of employment positions \\
\hline
\end{tabular}




\begin{tabular}{|l|l|l|l|}
\hline & categorization of job vacancies & $\begin{array}{l}\text { divisions of Dien Bien District } \\
\text { People's Committee }\end{array}$ & of 13 departments \\
\hline 6 & Build job descriptions & $\begin{array}{l}\text { Heads of 13 specialized } \\
\text { divisions of Dien Bien District } \\
\text { People's Committee }\end{array}$ & $\begin{array}{l}\text { Descriptions for each } \\
\text { position of 13 departments }\end{array}$ \\
\hline 7 & $\begin{array}{l}\text { Building the competency } \\
\text { framework for each job } \\
\text { position }\end{array}$ & $\begin{array}{l}\text { Heads of 13 specialized } \\
\text { divisions of Dien Bien District } \\
\text { People's Committee }\end{array}$ & $\begin{array}{l}\text { The capacity framework for } \\
\text { each position } \\
\text { departments }\end{array}$ \\
\hline 8 & $\begin{array}{l}\text { Determine the rank of civil } \\
\text { servants corresponding to the } \\
\text { job position }\end{array}$ & $\begin{array}{l}\text { Heads of 13 specialized } \\
\text { divisions of Dien Bien District } \\
\text { People's Committee }\end{array}$ & $\begin{array}{l}\text { The corresponding to the job } \\
\text { positions of 13 departments }\end{array}$ \\
\hline
\end{tabular}

(Source: Dien Bien District's Organizing Committee and Home Affairs from 2015 to 2019).

Comment on the process of building the project of job positions and civil servant rank structure of the People's Committee of Dien Bien district:

In terms of personal work statistics, the organization of specialized agencies under the District People's Committee has strictly, synchronously and promptly implemented to serve the agencies to develop job placement schemes for the organization. However, in general, the quality of the statistics is still very low, civil servants are still confused when declaring the job statistics, the statistics are not complete, have not described in detail, estimated time to perform the job tasks and describe difficult output products.

- Regarding the classification of work: The tasks are assigned to the Heads of the specialized agencies, but in general, the Heads of the specialized agencies will assign one civil servant specializing in statistics, synthesis and classification of work for the body. care about me. Therefore, the quality of the work grouping has not met the required quality, it is only superficial and general.

- Regarding the determination of influencing factors, it has not been properly explored, the guiding forms of the Ministry of Home Affairs are not realistic and difficult to understand, so it is difficult to identify the influencing factors and the agencies determine. There is almost no difference between agencies.

In terms of statistics, assessment of the current state of the contingent of civil servants of the agency has been fully implemented, thereby assessing the status of the contingent of civil servants in specialized agencies under the People's Committee of Dien Bien district.

- Regarding the determination of the list of job positions and the classification of the required job positions have been performed by specialized agencies, but the determination of the job position is not good, there is a lack of grounds for determining the job position. The job 
placement is still emotional and has not met the requirements of the project.

- Regarding the construction of job descriptions: Most specialized agencies have not yet developed job descriptions for each job position.

- In terms of capacity framework development, there are also many difficulties, specialized agencies of the People's Committee of Dien Bien district almost transfer the work statistics of individuals into job descriptions, without screening, appraisal, sorted by job position.

- Regarding the determination of the rank structure is not guaranteed, it is still general and depends on the specific people who are holding the position to make requirements on the rank structure of civil servants.

- Example of the proposal of the Organization and the Interior of Dien Bien district: currently there are 08 staff members, the construction unit has eight job positions, eight job descriptions, eight competency frameworks for eight locations. But in reality, if we guarantee, it must be ten job positions, ten job descriptions, ten capacity framework copies.

The survey results on the formulation of schemes for job positions and civil servant rank structure are shown in Table 4:

Table 4. Survey results on job replacement schemes

\begin{tabular}{|l|l|c|c|c|c|c|}
\hline No. & lontent & $\begin{array}{c}\text { Very } \\
\text { disagree }\end{array}$ & Disagree & Normal & Agree & $\begin{array}{c}\text { Very } \\
\text { agree }\end{array}$ \\
\hline 1 & $\begin{array}{l}\text { Full and reasonable job } \\
\text { position schemes }\end{array}$ & $15.25 \%$ & $50.45 \%$ & $17.53 \%$ & $16.77 \%$ & $0 \%$ \\
\hline 2 & $\begin{array}{l}\text { Detailed descriptions for each } \\
\text { full and scientific position }\end{array}$ & $30.25 \%$ & $43.67 \%$ & $15.88 \%$ & $10.2 \%$ & $0 \%$ \\
\hline 3 & $\begin{array}{l}\text { The rank structure of civil } \\
\text { servants ensures a solid legal } \\
\text { and practical basis }\end{array}$ & $13.45 \%$ & $30.54 \%$ & $40.84 \%$ & $15.17 \%$ & $0 \%$ \\
\hline 4 & $\begin{array}{l}\text { Competency framework is } \\
\text { required for a full, reasonable } \\
\text { and scientific job position }\end{array}$ & $0 \%$ & $30.35 \%$ & $69.65 \%$ & $0 \%$ & $0 \%$ \\
\hline
\end{tabular}

(Source: Dien Bien District Organizing Committee and Internal Affairs for 2018).

The survey results show that most of the respondents showed that they disagree with the complete and reasonable job placement project (50.45\% believe that they disagree); detailed description for each complete and scientific position (43.67\% disagree); The civil servant category structure ensures a solid legal and practical basis (30.54\% disagree); requirements for the competency framework for each suitable job position $(69.65 \%$ is normal, $30.35 \%$ disagrees). Therefore, the construction of job placement projects according to regulations of the Ministry of Home Affairs in specialized agencies under the People's Committee of Dien Bien district still has many shortcomings such as: The construction project is formalistic, not 
practical, not yet reasonable, not scientific; the detailed description for each position is not yet scientifically complete, does not fully reflect the job content, job processing time of each job position; The civil servant category has not been determined well, not close; the requirements for the capacity framework for each position are not reasonable and incomplete.

\subsection{Situation of Planning for Civil Servant Payroll, Civil Servant Planning}

Based on the job position scheme, every year, specialized agencies have strictly reported the district People's Committee on the results of using the staff assigned to the previous year; develop a plan, determine the needs of public servants to meet the job objectives to be performed in their departments. Propose solutions to implement the civil servant payroll plan after being assigned by the Provincial People's Committee, it is expected that the source of civil servants will be supplemented, replaced and implemented the policy of downsizing staffing, budgeting for main implementation. the staff streamlining book is submitted to the district People's Committee for appraisal, summed up and submitted to the Department of Home Affairs for appraisal, consolidation and submission to the Provincial People's Committee.

The planning of civil servants for leadership and management positions has been concerned and directed by the District People's Committee, and has periodically reviewed the planning of managerial leadership positions, promptly removed from the in the planning category who do not meet the prescribed conditions and standards; to select civil servants with sufficient qualifications and capabilities, meeting the prescribed conditions and standards to be added to the planning.

Regarding the process of developing the payroll plan, which is strictly carried out from the department level to the district People's Committee, the implementation progress has ensured on time as prescribed, the plan ensures proper determination of the necessary staff for each the specialized agency of the People's Committee of Dien Bien district. The Department of Organization and Home Affairs of Dien Bien district has well responsible for guiding agencies to develop annual plans, synthesize and advise the People's Committee of Dien Bien district to submit to competent authorities for consideration and appraisal according to regulations.

Table 5. Plan on payroll for civil servants at specialized agencies of the People's Committee of Dien Bien district

\begin{tabular}{|c|c|c|c|c|c|c|c|c|c|c|c|}
\hline \multirow[t]{2}{*}{ No. } & Types & \multicolumn{2}{|c|}{2015} & \multicolumn{2}{|c|}{2016} & \multicolumn{2}{|c|}{2017} & \multicolumn{2}{|c|}{2018} & \multicolumn{2}{|c|}{2019} \\
\hline & $\begin{array}{l}\text { The total number of } \\
\text { payroll civil servants at } \\
\text { the specialized } \\
\text { agencies of the People's } \\
\text { Committee of Dien Bien } \\
\text { district }\end{array}$ & 117 & $\begin{array}{c}\text { Ratio } \\
\%\end{array}$ & 117 & $\begin{array}{c}\text { Ratio } \\
\%\end{array}$ & 112 & $\begin{array}{l}\text { Rati } \\
\text { o \% }\end{array}$ & 110 & $\begin{array}{c}\text { Ratio } \\
\%\end{array}$ & 95 & $\begin{array}{l}\text { Rat } \\
\text { io } \\
\%\end{array}$ \\
\hline
\end{tabular}




\begin{tabular}{|c|c|c|c|c|c|c|c|c|c|c|c|}
\hline 1 & $\begin{array}{l}\text { Office of People's } \\
\text { Councils and People's } \\
\text { Committees of districts }\end{array}$ & 24 & 20.5 & 24 & 20.5 & 25 & 22.4 & 23 & 21.0 & 23 & $\begin{array}{l}24 . \\
1\end{array}$ \\
\hline 2 & $\begin{array}{l}\text { Organizing Committee } \\
\text { and Interior }\end{array}$ & 9 & 7.7 & 9 & 7.7 & 8 & 7.1 & 7 & 6.4 & 0 & \\
\hline 3 & $\begin{array}{l}\text { Inspection committee - } \\
\text { inspection }\end{array}$ & 8 & 6.8 & 8 & 6.8 & 7 & 6.3 & 7 & 6.4 & 0 & \\
\hline 4 & $\begin{array}{l}\text { Department of } \\
\text { Agriculture and Rural } \\
\text { development }\end{array}$ & 11 & 9.4 & 11 & 9.4 & 11 & 9.8 & 11 & 10.0 & 11 & $\begin{array}{l}11 . \\
6\end{array}$ \\
\hline 5 & $\begin{array}{l}\text { Economic and } \\
\text { Infrastructure division }\end{array}$ & 8 & 6.8 & 8 & 6.8 & 9 & 8.0 & 9 & 8.2 & 9 & 9.5 \\
\hline 6 & $\begin{array}{l}\text { Financial planning } \\
\text { office }\end{array}$ & 13 & 11.1 & 13 & 11.1 & 14 & 12.5 & 14 & 12.6 & 14 & $\begin{array}{l}14 . \\
7\end{array}$ \\
\hline 7 & $\begin{array}{l}\text { Resources and } \\
\text { Environmental office }\end{array}$ & 9 & 7.7 & 9 & 7.7 & 9 & 8.0 & 10 & 9.1 & 9 & 9.5 \\
\hline 8 & Judicial departments & 5 & 4.3 & 5 & 4.3 & 4 & 3.6 & 3 & 2.7 & 3 & 3.2 \\
\hline 9 & $\begin{array}{l}\text { Education and training } \\
\text { room }\end{array}$ & 9 & 7.7 & 9 & 7.7 & 8 & 7.1 & 8 & 7.3 & 8 & 8.4 \\
\hline 10 & $\begin{array}{ll}\text { Culture } & \text { and } \\
\text { information office } & \end{array}$ & 3 & 2.6 & 3 & 2.6 & 2 & 1.8 & 2 & 1.9 & 2 & 2.1 \\
\hline 11 & $\begin{array}{l}\text { District labor - Invalids } \\
\text { and Social Affairs } \\
\text { division }\end{array}$ & 9 & 7.7 & 9 & 7.7 & 8 & 7.1 & 9 & 8.2 & 9 & 9.5 \\
\hline 12 & Public health station & 4 & 3.4 & 4 & 3.4 & 3 & 2.7 & 3 & 2.7 & 3 & 3.2 \\
\hline 13 & Ethnic room & 5 & 4.3 & 5 & 4.3 & 4 & 3.6 & 4 & 3.5 & 4 & 4.2 \\
\hline
\end{tabular}

(Source: Plan on payroll of civil servants at specialized agencies of the People's Committee of Dien Bien district from 2015-2019)

The construction of the Master Plan for Civil Servants has also been implemented regularly, promptly, publicly and transparently, thereby selecting civil servants with strong political, personal ethics and professional qualities to bring into the planning of leadership and management positions of specialized agencies under the People's Committee of Dien Bien district. In addition, there are also some cases where the planning of civil servants does not meet the prescribed standards and conditions. 
Table 6. Survey results on payroll planning, civil servant planning at specialized agencies of Dien Bien District People's Committee

\begin{tabular}{|l|l|l|l|l|l|l|}
\hline No. & Content & $\begin{array}{c}\text { Very } \\
\text { disagree }\end{array}$ & Disagree & Normal & Agree & $\begin{array}{c}\text { Very } \\
\text { agree }\end{array}$ \\
\hline 1 & $\begin{array}{l}\text { The planning of civil servant payroll } \\
\text { by the People's Committee of Dien } \\
\text { Bien district is accurate and } \\
\text { scientific }\end{array}$ & $0 \%$ & $0 \%$ & $8.67 \%$ & $70.2 \%$ & $21.13 \%$ \\
\hline 2 & $\begin{array}{l}\text { Planning for civil servants to } \\
\text { specialized agencies of the People's } \\
\text { Committee of Dien Bien district is } \\
\text { regular, objective and scientific }\end{array}$ & $0 \%$ & $0 \%$ & $25.50 \%$ & $59.25 \%$ & $15.25 \%$ \\
\hline
\end{tabular}

(Source: Organizing Committee and Internal Affairs, compiled in December 2019)

Through Table 6, the survey results show that the implementation of the planning of civil servant payroll, civil servant planning has been done relatively well and ensures objectivity, transparency, and timely meeting the requirements. demand for content and time according to regulations: $70.2 \%$ of public employee payroll planning is accurate and scientific; $74.5 \%$ of respondents think that planning on civil servants is regular, objective and scientific.

\subsection{Current Situation of Civil Servant Recruitment}

Pursuant to the 2008 Law on Cadres and Civil Servants; implementing Decision No. 04/2010 / QD-UBND dated 31/5/2010 of the People's Committee of the Delta Province on decentralizing management apparatus, payroll of state administrative agencies in Dien Bien province.

Based on the requirements of the task, job position and the payroll plan assigned by the provincial People's Committee, when there is a need to recruit civil servants, the District People's Committee has implemented the recruitment of civil servants in accordance with the specific order and procedures. Such as: Developing recruitment plans and submitting them to the Department of Home Affairs, a specialized agency to help the Provincial People's Committee perform the function of state management of payrolls, and civil servants to appraise and approve recruitment plans.

After the recruitment plan was approved by the Department of Home Affairs, the District People's Committee announced publicly on the mass media the quantity and recruitment targets; requirements on conditions and standards of vacancies; form of recruitment (entrance examination, admission, admission without passing exams); time and place to receive recruitment documents; implement the process of receiving recruitment dossiers according to the recruitment plan approved by the Department of Home Affairs; issue a decision to establish an examination council or examination council and organize an examination, selection and examination in case of non-admission; organize entrance examination, examination, test and notify the results of entrance examination, examination and 
examination in case of not receiving the examination;

After the council meeting to review and submit to the Department of Home Affairs for appraisal and approval of the results of the entrance examination, admission, examination in case of not receiving the examination. After there is a decision approving the results of the entrance examination, admission, and examination in the case of receiving no examination, the District People's Committee issues a recruitment decision for the successful candidates.

Table 7. Results of recruiting civil servants at specialized agencies under the People's Committee of Dien Bien district for the period 2015-2019

\begin{tabular}{|l|l|l|l|l|l|l|l|l|l|l|l|}
\hline No. & Classification & \multicolumn{2}{|c|}{2015} & \multicolumn{2}{c|}{2016} & \multicolumn{2}{c|}{2017} & \multicolumn{2}{c|}{2018} & \multicolumn{2}{c|}{2019} \\
\hline & $\begin{array}{l}\text { Quan } \\
\text {-tity }\end{array}$ & Ratio & $\begin{array}{l}\text { Quan } \\
\text {-tity }\end{array}$ & Ratio & $\begin{array}{l}\text { Quan } \\
\text {-tity }\end{array}$ & Ratio & $\begin{array}{l}\text { Quan } \\
\text {-tity }\end{array}$ & Ratio & $\begin{array}{l}\text { Quan } \\
\text {-tity }\end{array}$ & Ratio \\
\hline 1 & $\begin{array}{l}\text { Recruitment } \\
\text { plan }\end{array}$ & 7 & & 4 & & 2 & & 0 & & 2 & \\
\hline 2 & $\begin{array}{l}\text { Recruitment } \\
\text { results }\end{array}$ & 7 & $\begin{array}{l}100 \\
\%\end{array}$ & 4 & $\begin{array}{l}100 \\
\%\end{array}$ & 2 & $\begin{array}{l}100 \\
\%\end{array}$ & 0 & & 2 & $\begin{array}{l}100 \\
\%\end{array}$ \\
\hline & - Examination & 0 & & 0 & & 0 & & 0 & & 0 & \\
\hline & - Admission & 7 & $\begin{array}{l}100 \\
\%\end{array}$ & 4 & $\begin{array}{l}100 \\
\%\end{array}$ & 2 & $\begin{array}{l}100 \\
\%\end{array}$ & 0 & & 2 & $\begin{array}{l}100 \\
\%\end{array}$ \\
\hline
\end{tabular}

(Source: Organizers and internal affairs from 2015-2019)

Through Table 7, the results of recruiting civil servants in specialized agencies under the People's Committee of Dien Bien district show that the recruitment of civil servants for specialized agencies under the People's Committee of Dien Bien district is completely done by the method of public employee recruitment, On average, each year 03 people are recruited to supplement the specialized agencies.

Table 8. Results of the survey on civil servant recruitment in specialized agencies of Dien Bien District People's Committee

\begin{tabular}{|l|l|c|c|c|c|c|}
\hline No. & Content & $\begin{array}{c}\text { Very } \\
\text { disagree }\end{array}$ & Disagree & Normal & Agree & $\begin{array}{c}\text { Very } \\
\text { agree }\end{array}$ \\
\hline 1 & $\begin{array}{l}\text { Method of selection of civil servants } \\
\text { is reasonable, objectively }\end{array}$ & $0 \%$ & $0 \%$ & $5.25 \%$ & $55.77 \%$ & $38.98 \%$ \\
\hline 2 & $\begin{array}{l}\text { Recruitment steps ensure objectivity, } \\
\text { publicity and transparency }\end{array}$ & $0 \%$ & $0 \%$ & $15.74 \%$ & $67.11 \%$ & $17.15 \%$ \\
\hline 3 & $\begin{array}{l}\text { Examination and admission of civil } \\
\text { servants ensure selection of people } \\
\text { who meet the requirements of the } \\
\text { vacancy }\end{array}$ & $0 \%$ & $0 \%$ & $45.2 \%$ & $39.35 \%$ & $15.45 \%$ \\
\hline
\end{tabular}


(Source: Organizing Committee and General Internal Affairs in 2019)

Table 8 of the survey results on the recruitment of civil servants in specialized agencies under the People's Committee of Dien Bien district shows that the implementation of the recruitment of civil servants has ensured the reasonableness, objectivity, publicity and transparency (rated over $60 \%$ of respondents agree, below $20 \%$ is normal). The steps taken in the recruitment process ensure public and transparent answers, resulting in over $60 \%$ of respondents agree. The selection ensures the selection of people who meet the requirements of the vacancy with over $40 \%$ of respondents agreeing.

\subsection{Current Situation of Using Civil Servants}

\section{About the arrangement of civil servants}

The arrangement of civil servants by job position for new recruits, the District People's Committee has arranged jobs for them in accordance with the previously recruited position, arranged trainee instructors for people. For those who has been recruited in the form of admission without passing the examination, had experience in the work, based on the demand for the position before receiving the job to arrange jobs for the person received by the District People's Committee.

Table 9. Table of arrangement of civil servants at specialized agencies under the People's Committee of Dien Bien district for the period 2015-2019

\begin{tabular}{|l|l|c|c|c|c|c|c|}
\hline No. & Classification & 2015 & 2016 & 2017 & 2018 & 2019 & Note \\
\hline 1 & Total number of people employed & 7 & 4 & 2 & 0 & 2 & \\
\hline 2 & $\begin{array}{l}\text { Number of people is arranged } \\
\text { correctly }\end{array}$ & 7 & 4 & 2 & 0 & 2 & $\begin{array}{l}\text { The number of people has not been } \\
\text { properly arranged }\end{array}$ \\
\hline 3 & 0 & 0 & 0 & 0 & 0 & \\
\hline
\end{tabular}

Source: Organizing Committee and Internal Affairs, compiled in December 2015, 2016, 2017 , 2018, 2019)

The arrangement of civil servants after being recruited was arranged correctly by the District People's Committee according to the vacancy, but there is still 01 case of recruitment in 2015 that has not been properly arranged with the vacancy (Table 9).

\section{About mobilizing civil servants}

The mobilization of civil servants is done based on the functions, tasks, employment positions and the number of staff assigned to the specialized agencies of the district People's Committee; when there is a need to transfer civil servants from one agency to another; The District People's Committee has carried out the transfer of civil servants according to the requirements of the job position on the basis that the mobilized civil servant must meet the professional requirements suitable to the new job position. 
Table 10. Table of dispatching civil servants at specialized agencies of the People's Committee of Dien Bien district for the period 2015-2019

\begin{tabular}{|l|l|c|c|c|c|c|}
\hline No. & Classification & 2015 & 2016 & 2017 & 2018 & 2019 \\
\hline 1 & Number of people mobilized & 8 & 5 & 6 & 4 & 2 \\
\hline 2 & $\begin{array}{l}\text { The rate of civil servants being } \\
\text { transferred }\end{array}$ & $7.34 \%$ & $4.67 \%$ & $6.06 \%$ & $4.08 \%$ & $2.15 \%$ \\
\hline
\end{tabular}

(Source: Organizing Committee and Internal Affairs gathered in December 2015, 2016, 2017 , 2018, 2019)

The number of people mobilized is not much, on average, accounting for less than $5 \%$ per year. Thereby ensuring to avoid disturbance to the organization of specialized agencies under the People's Committee of Dien Bien district, the arrangement of civil servants has ensured that most of the positions are suitable for the capacity and working skills of civil servants (Table 10).

About the appointment of civil servants

The appointment of civil servants to leadership and manager positions: Based on the needs and tasks of the specialized agencies of the District People's Committee; Standards and conditions of each leadership position, management and planning have been approved, when there is a need to consolidate and appoint civil servants, the District People's Committee has appointed leading civil servants, managing the agency in accordance with authority, order, procedures and decentralized management of the Provincial People's Committee.

Table 11. Table of appointment of civil servants at specialized agencies under the People's Committee of Dien Bien district for the period 2015-2019

\begin{tabular}{|l|l|c|c|c|c|c|}
\hline No. & Classification & 2015 & 2016 & 2017 & 2018 & 2019 \\
\hline 1 & $\begin{array}{l}\text { Total number of civil } \\
\text { servants appointed }\end{array}$ & 9 & 5 & 6 & 4 & 0 \\
\hline 2 & Number of appointments & 3 & 2 & 3 & 1 & 0 \\
\hline 3 & $\begin{array}{l}\text { The proportion of civil } \\
\text { servants appointed }\end{array}$ & $7.7 \%$ & $4.27 \%$ & $5.4 \%$ & $3.6 \%$ & $0 \%$ \\
\hline
\end{tabular}

(Source: Organizing Committee and Internal Affairs gathered in December 2015, 2016, 2017, 2018, 2019)

Through Table 11, the appointment of civil servants shows that the implementation of the appointment of civil servants is stable about 4 to 5 percent per year.

\section{About rotation of civil servants}

The rotation of civil servants: is implemented by the District People's Committee based on the requirements of the provincial People's Committee based on task requirements, 
planning, and plans for the employment of civil servants, leading civil servants, and managers and according to the regulations on management decentralization of the Provincial People's Committee. The District People's Committee has rotated a number of leading civil servants at the department level under the District People's Committee to be key leaders at the commune level in order to create conditions for civil servants to access many fields, environment and working conditions. the basis from which to select qualified and qualified civil servants as the basis for the planning, promotion and appointment of civil servants to higher positions.

Table 12. Table of civil servant rotation in specialized agencies of Dien Bien District People's Committee, period 2015-2019

\begin{tabular}{|l|l|c|c|c|c|c|}
\hline No. & Classification & 2015 & 2016 & 2017 & 2018 & 2019 \\
\hline 1 & $\begin{array}{l}\text { The total number of civil servants } \\
\text { to be rotated }\end{array}$ & 3 & 0 & 5 & 0 & 0 \\
\hline 2 & $\begin{array}{l}\text { Number of rotations } \\
3\end{array}$ & $\begin{array}{l}\text { Rate of civil servants being } \\
\text { rotated \% compared to the total } \\
\text { number of civil) }\end{array}$ & $2.6 \%$ & $0 \%$ & $4.5 \%$ & $0 \%$ \\
\hline
\end{tabular}

(Source: Organizing Committee and Internal Affairs gathered in December years 2015, 2016, 2017, 2018, 2019)

The rotation of civil servants is carried out in order to train civil servants in leadership positions and manage specialized agencies under the People's Committee of Dien Bien district to experience practical, practice skills, and improve experience. then returned to a higher position in the specialized agencies of the People's Committee of Dien Bien district.

In general, the staff rotation has been actively implemented, although there are still difficulties in the process of implementation, but there are results. Rotated civil servants are well-fulfilled, mature in all aspects, are a young force with good prospects for development, capable of approaching leadership positions in the future. However, in the implementation process, there are still shortcomings and limitations that need to be further studied and overcome as follows: The number of rotating civil servants is not much compared to the actual capacity of the contingent of civil servants. plan; the rotation within the district has just been implemented in a number of agencies, the rotation down to grassroots has not been done much; the district's own regimes and policies have not yet been built to encourage and encourage civil servants to rotate.

\subsection{Status of Training and Retraining of Civil Servants}

Based on the quality status of the contingent of civil servants of departments, the district People's Committee determines the training and retraining objectives and needs of civil servants under the district People's Committee. Every year, the District People's Committee has directed the Organization and Home Affairs Committee to conduct surveys and assess 
the quality of civil servants under the District People's Committee as a basis for building training and retraining plans for the contingent of civil servants under the People's Committee. District. The Department of Organization and Home Affairs advises the District People's Committee to have documents guiding specialized agencies to survey and register the training and retraining needs of civil servants in specialized agencies under the district People's Committee. After submitting the survey results and the list of registration for training and retraining needs of civil servants, the District Department of Organization and Home Affairs synthesizes and reports to Dien Bien District People's Committee.

Table 13. Table of plans for training and retraining civil servants at specialized agencies of the People's Committee of Dien Bien district for the period 2015-2019

\begin{tabular}{|c|c|c|c|c|c|c|c|c|c|c|c|}
\hline \multirow{2}{*}{$\begin{array}{l}\mathrm{N} \\
\mathrm{o}\end{array}$} & \multirow[b]{2}{*}{ Classification } & \multicolumn{2}{|c|}{2015} & \multicolumn{2}{|c|}{2016} & \multicolumn{2}{|c|}{2017} & \multicolumn{2}{|c|}{2018} & \multicolumn{2}{|c|}{2019} \\
\hline & & $\begin{array}{l}\text { Quan } \\
\text {-tity }\end{array}$ & Ratio & $\begin{array}{l}\text { Quan } \\
\text {-tity }\end{array}$ & Ratio & $\begin{array}{l}\text { Quan } \\
\text {-tity }\end{array}$ & Ratio & $\begin{array}{l}\text { Quan } \\
\text {-tity }\end{array}$ & Ratio & $\begin{array}{l}\text { Quan } \\
\text {-tity }\end{array}$ & Ratio \\
\hline 1 & $\begin{array}{l}\text { - Number of } \\
\text { civil servants } \\
\text { to be trained }\end{array}$ & 15 & 12.8 & 15 & 12.8 & 15 & 13.4 & 15 & 13.6 & 15 & 15.8 \\
\hline & $\begin{array}{l}\text { - Send to } \\
\text { training } \\
\text { Master }\end{array}$ & 04 & 3.4 & 4 & 3.4 & 5 & 4.5 & 4 & 3.6 & 05 & 5.3 \\
\hline & $\begin{array}{l}\text { - Send out to } \\
\text { train } \\
\text { bachelors and } \\
\text { engineers }\end{array}$ & 11 & 9.4 & 11 & 9.4 & 10 & 8.9 & 11 & 10.0 & 10 & 10.5 \\
\hline & $\begin{array}{l}\text { - Bachelor, } \\
\text { engineer }\end{array}$ & 35 & 29.9 & 30 & 25.6 & 25 & 22.3 & 17 & 15.5 & 14 & 14.7 \\
\hline 2 & $\begin{array}{l}\text { Number of } \\
\text { civil servants } \\
\text { to be fostered }\end{array}$ & 40 & 34.2 & 40 & 34.2 & 38 & 33.9 & 40 & 36.4 & 39 & 41.0 \\
\hline & $\begin{array}{l}\text { - Fostering in } \\
\text { the district }\end{array}$ & 30 & 25.6 & 30 & 25.6 & 29 & 25.9 & 30 & 27.3 & 30 & 31.6 \\
\hline & $\begin{array}{l}\text { - Fostering in } \\
\text { the province, } \\
\text { Central }\end{array}$ & 10 & 8.6 & 10 & 8.6 & 9 & 8.0 & 10 & 9.0 & 9 & 9.4 \\
\hline
\end{tabular}

(Source: Organizing Committee and Internal Affairs gathered in December 2015, 2016, 2017, 2018, 2019) 


\section{Ml Macrothink}

The plan of training and retraining civil servants in specialized agencies under the People's Committee of Dien Bien district has closely adhered to the requirements of the job position that requires training and retraining. Develop a plan based on the ability of the training budget that has been allocated to the DPC, based on the work situation of the specialized agencies under the District People's Committee, specifically in some contents:

Regarding the order of sending to training, it is approved through 02 levels: The professional division meeting is considered according to the assigned plan targets; After issuing the room on the basis of conditions and criteria for the meeting, the proposal is submitted to the DPC. The District People's Committee will set up a Council to consider and appoint civil servants to be trained once a year.

The order of sending civil servants to foster training will be done before the schools and fostering centers have open classes to train civil servants. The specialized agencies based on the plans and norms that have been assigned to meet to consider the conditions and criteria of the person being sent for training. After the meeting to consider transferring the district People's Committee, the People's Committee of Dien Bien district will set up a Council to consider sending civil servants for training according to the approved training and retraining plan.

If classes are opened in the district, the District People's Committee will assign the Organizing and Home Affairs Board to coordinate with relevant agencies to organize the opening of classes, review the content, programs and methods of training and retraining civil servants. . Appraisal of contents, reporting program to the District People's Committee for approval before opening the training and retraining class of civil servants.

For the training and retraining classes approved by the provincial and central levels, the District People's Committee only assigns specialized agencies with civil servants to attend classes, monitoring and checking the process. learning of civil servants participating in training and retraining.

Table 14. Table of results of training and retraining civil servants at specialized agencies of Dien Bien District People's Committee, period 2015-2019

\begin{tabular}{|l|l|l|l|l|l|l|l|l|l|l|l|}
\hline \multirow{2}{*}{ No. } & \multirow{2}{*}{ Classification } & \multicolumn{2}{|c|}{2015} & \multicolumn{2}{c|}{2016} & \multicolumn{2}{c|}{2017} & \multicolumn{2}{c|}{2018} & \multicolumn{2}{c|}{2019} \\
\cline { 2 - 12 } & Quan & Ratio & $\begin{array}{l}\text { Quan } \\
\text {-tity }\end{array}$ & Ratio & $\begin{array}{l}\text { Quan } \\
\text {-tity }\end{array}$ & Ratio & $\begin{array}{l}\text { Quan } \\
\text {-tity }\end{array}$ & Ratio & $\begin{array}{l}\text { Quan } \\
\text {-tity }\end{array}$ & Ratio \\
\hline & $\begin{array}{l}\text { Number of } \\
\text { trained civil } \\
\text { servants }\end{array}$ & 7 & 6.0 & 7 & 6.0 & 11 & 9.8 & 11 & 100 & 08 & 8.4 \\
\hline & $\begin{array}{l}\text { Master } \\
\text { training }\end{array}$ & 2 & 1.7 & 0 & & 2 & 1.8 & 2 & 1.8 & 01 & 1.0 \\
\hline $\begin{array}{l}\text { Training } \\
\text { Bachelor, }\end{array}$ & 5 & 4.3 & 7 & 6.0 & 9 & 8.0 & 9 & 8.2 & 07 & 7.4 \\
\hline
\end{tabular}




\begin{tabular}{|l|l|l|l|l|l|l|l|l|l|l|l|}
\hline 2 & engineers & & & & & & & & & \\
\hline $\begin{array}{l}\text { CC number to } \\
\text { be trained }\end{array}$ & 15 & 12.8 & 14 & 12.0 & 16 & 14.3 & 12 & 11.0 & 12 & 12.6 \\
\hline $\begin{array}{l}- \text { Fostering in } \\
\text { the district } \\
\text { twelfth }\end{array}$ & 12 & 10.3 & 11 & 9.4 & 3 & 2.7 & 9 & 8.2 & 09 & 9.5 \\
\hline $\begin{array}{l}\text { - Fostering in } \\
\text { the province, } \\
\text { Central }\end{array}$ & 3 & 2.5 & 3 & 2.6 & 13 & 11.6 & 3 & 2.8 & 03 & 3.1 \\
\hline
\end{tabular}

(Source: Organizing Committee and Internal Affairs gathered in December 2015, 2016, 2017, 2018, 2019)

Through the table 14 above-mentioned results of training and retraining civil servants, the plan for training and retraining civil servants is not good, with targets exceeding the plan, with targets met and targets not meeting the plan's requirements.

\subsection{Remuneration for Civil Servants}

Due to the State's regulations on the remuneration of civil servants, within the scope of their assigned competence, in order to well implement the civil servant remuneration regime, the District People's Committee has regularly urged, examined and inspected the implementation of the regime. to provide civil servants with remuneration to ensure the compliance with current regulations of the State, and at the same time, raise the salary rank ahead of time for civil servants who successfully complete their tasks; sending civil servants to attend rank promotion exams; Using the regular budget saved annually to pay bonuses, support for civil servants, visit and encourage civil servants during holidays, New Year, when civil servants have filial; commend according to competence or propose to competent authorities to reward public servants with outstanding achievements in performing annual work tasks, with outstanding achievements in performing extraordinary work tasks and perform thematic tasks, thereby creating motivation for civil servants to strive in the process of implementing assigned tasks (Table 15).

Table 15. Remuneration for civil servants at specialized agencies under the management of the People's Committee of Dien Bien district in the period 2015-2019

\begin{tabular}{|l|l|c|c|c|c|c|}
\hline No. & Classification & 2015 & 2016 & 2017 & 2018 & 2019 \\
\hline 1 & $\begin{array}{l}\text { Number of civil servants proposed } \\
\text { to raise salaries ahead of time }\end{array}$ & 11 & 10 & 9 & 8 & 8 \\
\hline 2 & $\begin{array}{l}\text { Number of civil servants proposed } \\
\text { to take the public servant rank } \\
\text { promotion exam }\end{array}$ & 0 & 0 & 0 & 11 & 7 \\
\hline
\end{tabular}




\begin{tabular}{|l|l|l|l|l|l|l|}
\hline 3 & $\begin{array}{l}\text { Number of civil servants proposing } \\
\text { commendation }\end{array}$ & \multicolumn{1}{|c|}{45} & \multicolumn{1}{|c|}{32} & 30 & 31 \\
\hline 4 & $\begin{array}{l}\text { The total amount the District } \\
\text { People's Committee allocates to pay } \\
\text { civil servants for overtime }\end{array}$ & $\begin{array}{l}200 \\
\text { millions } \\
\text { VND }\end{array}$ & $\begin{array}{l}200 \\
\text { millions } \\
\text { VND }\end{array}$ & $\begin{array}{l}200 \\
\text { millions } \\
\text { VND }\end{array}$ & $\begin{array}{l}200 \\
\text { millions } \\
\text { VND }\end{array}$ & $\begin{array}{l}200 \\
\text { millions } \\
\text { VND }\end{array}$ \\
\hline 5 & $\begin{array}{l}\text { Total funds saved from recurrent } \\
\text { expenditure sources (5\%) to } \\
\text { allocate remuneration for civil }\end{array}$ & $\begin{array}{l}500 \\
\text { millions } \\
\text { VND }\end{array}$ & $\begin{array}{l}500 \\
\text { millions } \\
\text { VND }\end{array}$ & $\begin{array}{l}500 \\
\text { millions } \\
\text { VND }\end{array}$ & $\begin{array}{l}500 \\
\text { millions } \\
\text { VND }\end{array}$ & $\begin{array}{l}500 \\
\text { millions } \\
\text { VND }\end{array}$ \\
\hline
\end{tabular}

(Source: Organizing Committee and Internal Affairs gathered in December 2015, 2016, 2017 , 2018, 2019)

\section{Situation Assessment of Civil Servant Management in Dien Bien District, Dien Bien Province, Vietnam}

\subsection{Result}

- In the past years, especially from 2015 up to now, together with the implementation of the contents of the State administrative reform program of the province and the district in the period 2015-2020 and the real implementation currently the Law on Cadres and Civil Servants. The management of civil servants of the People's Committee of Dien Bien District has been concerned, directed and organized by the leaders of the District People's Committee, which is quite serious, in accordance with the current order, procedures and regulations of the State and the province. The quality of the management of civil servants has been gradually improved, basically meeting the task requirements in the state administrative reform process and suitable with local practical conditions.

- Regarding the determination of job positions and the rank structure of civil servants, has been seriously, publicly and promptly implemented, ensuring the required time.

- Regarding the construction of the plan for civil servant payrolls, the planning for civil servants is done to ensure objectivity and accuracy, determine the number of necessary payrolls, ensure to perform the functions and tasks of the agencies. expertise under the People's Committee of Dien Bien district. Planning for civil servants with the right people, selecting qualified, ethical, skilled and standard civil servants to be included in the planning for the leadership and managerial positions from then on as a basis for building plan training and retraining of civil servants in the planning.

- Recruitment of civil servants is done publicly, objectively, transparently, correctly, fully, to ensure the prescribed process. Thereby ensuring the number of retired civil servants, resigned, transferred to work ... Therefore, it has also contributed to improving the quality of the contingent of civil servants in specialized agencies under the People's Committee of Dien Bien district.

- Regarding the arrangement and use of civil servants has also been done well, the arrangement and use of civil servants has been based on the civil servants' capacities, 
strengths and expertise, thereby contributing to stabilizing the organizational apparatus. expertise of Dien Bien District People's Committee.

- Regarding the training and retraining of civil servants, the quality of the contingent of civil servants in specialized agencies under the People's Committee of Dien Bien district has been improved. Encouraging other civil servants to strive and study to improve the qualifications of civil servants.

- Remuneration for civil servants is done properly, fully and promptly, encouraging civil servants to be enthusiastic in their work. With legal income, ensuring the life of civil servants in specialized agencies under the People's Committee of Dien Bien district.

\subsection{Restrictions}

In addition to the results achieved, in the management of civil servants of the People's Committee of Dien Bien District, there are still limitations and weaknesses that need to be overcome, including:

- The construction of the scheme of job positions and the rank structure of civil servants is still formalistic and does not ensure the required quality.

- The development of district civil servant development plans and plans have not been carried out methodically, not in time, and have not met the requirements of the development in the period of accelerating industrialization and modernization. and international integration; The planning of civil servants is sometimes of a relationship, family, respect, not really selecting talented and virtuous people to put into planning, fostering for the future.

- The management, use and arrangement of the contingent of civil servants is not suitable for the job position, the rank structure of civil servants, so the quality and efficiency of the work are not high; promotion and appointment of leading civil servants and managers of specialized agencies under the District People's Committee are sometimes still contradictory.

- The implementation of developing training and retraining plans met many difficulties such as: Budget to support training, allocating time for civil servants to participate in learning to improve qualifications outside the province. The very few proportion of civil servants with high professional qualifications has greatly limited to building a core civil servant force to carry out strategic and urgent tasks when necessary. The appointment of civil servants to train, foster or always move to other positions to raise awareness of reasoning, practical experience for promotion and appointment to higher positions when in love. demand is still very limited.

- The assessment of civil servants is not deep, mainly qualitative, without quantitative methods. The assessment is still very respectful, mainly based on the self-comments of civil servants, has not brought into play the comments and assessments of management superiors, agencies, colleagues, individuals and groups. function is related to the job position of the civil servant.

- Regarding remuneration, civil servants have not really attracted people with high qualifications and working experience in specialized agencies under the People's Committee 
of Dien Bien district. Due to the rigid mechanisms and policies for remuneration for civil servants, it is not guaranteed to encourage civil servants.

\subsection{Cause}

\section{Objective reasons}

- The system of legal documents on recruitment, management, use, promotion, appointment, evaluation, and rotation of cadres and civil servants has been gradually completed, but there are still many shortcomings. In terms of organizational management decentralization, the organizational apparatus, staffing staff and civil servants of the Provincial People's Committee still have many shortcomings but are slowly being revised and supplemented to suit management practices.

- Due to the decentralization of the management of civil servants in the province has not changed promptly according to the regulations on the management of public servants of the Government, ministries and central branches.

- The payroll plan is appraised by the province and submitted to the Ministry of Home Affairs and the Government for approval with the number of civil servants not meeting the plan submitted by the District People's Committee.

- The implementation of downsizing the payroll at the request of the Party and the State led to the request for staff reduction, which also greatly affected the number of civil servants in specialized agencies under the People's Committee of Dien Bien district.

- State budget source allocated by the district People's Committee to specialized agencies under the district People's Committee to implement training and retraining work is still slow, not ensuring the plan's estimate.

\section{Subjective reasons}

- The attention and direction of leaders of the People's Committee of Dien Bien district are not really close, not paid enough attention.

- Due to the recurrent expenditure and the expenditure for the annual training and retraining of cadres and civil servants, the district People's Committee depends on the provincial budget; State budget revenues in the district are still very limited, so the District People's Committee has not really paid attention to training and retraining to improve the qualifications in all aspects of the contingent of civil servants, so that part of the budget has not been spent for the district's own remuneration policy for a contingent of excellent, capable and talented civil servants.

- The political system is still heavy on the asking-giving mechanism, not really keeping up with the socio-economic development. Regulations on management of civil servants are still rigid and incomplete; The rotation, transfer, and secondment of civil servants from working positions in one agency to working positions in other agencies, from district-level civil servants to communal levels to raise awareness of political theory, professional expertise and practical experience to create a strategic source of staff and for promotion and appointment to 
higher positions when the request is not timely.

- Although the promulgation of provincial support policies for cadres and civil servants going to school and attending training and retraining classes to improve their qualifications is still low, not keeping up with the changes of the situation. social economy, but some civil servants have not actively registered to attend training courses to improve their professional qualifications and skills with socialization funding, still relying on policies support from the province and the district.

- The initiative and creativity of a part of civil servants, including leading and managerial civil servants, is limited, and still expects and depends on superiors. A few cadres leading and managing specialized agencies under the District People's Committee, especially newly appointed cadres, because they do not have much experience in management practice, they are still passive in organizing, only directing and operating the agency's activities. At each time, each task, the direction and administration of the agency's activities is still situational and not strategic.

\section{Recommendation to Improve Civil Servant Management in Dien Bien District, Dien Bien Province, Vietnam in the Context of International Economic Integration}

\subsection{Completing and Developing Projects of Job Positions and Civil Servant Category Structure}

Construction of job positions in addition to using synthetic methods (combining organizational analysis, work analysis) must also use experience statistics method, this method will support the synthesis method. when constructing job positions, especially defining the required payroll. The statistical method of experience requires managers (at the level of Head, Deputy Head of the unit, Head of Department, Deputy Head of Department ... ) to carefully study the current structure of the agencies, carefully analyze the position of each person., draw out advantages, eliminate duplication, overlap and inappropriateness to determine the appropriate staffing and civil servant structure.

Build job analysis of each job position. Job description The analysis and job description must be built based on the functions, tasks and powers of the unit. The content of job analysis must be scientific, ensuring a close link between job descriptions (including specific jobs, responsibilities, tasks) and professional title standards (including skills, professional qualifications subjects, experience) of civil servants. The work analysis should specify the work handling processes, the time required to perform work processes in accordance with the law or the agency.

Enhancing the role of the head of the agency in developing the job position and civil servant structure in the agency is very important. The head must be the person who best knows the characteristics of all the agencies under his management as well as the manpower needs of each affiliated unit. Therefore, in the process of implementing and building the Job placement Project in the unit, the Head of the unit must direct all affiliated units to coordinate with their staff to directly build the Project. Leaders of affiliated units must accurately assess the current workload, the ability to meet the workload of civil servants in the unit and expect new jobs to 
arise in the future to serve as a basis for proposals. the necessary number of staff members ensures objectivity, thrift and efficiency.

\subsection{Speed up the Development of Public Servant Management Plans}

Review the assigned payrolls of each department, evaluate all district civil servants on: qualifications, training majors, professional ability compared to with the requirements of each job position to have a basis for the proposed plan of civil servant re-arrangement according to the job position. Completing the civil servant re-arrangement plan: Assigning specific personnel to each job position, in accordance with the prescribed standards of qualifications, training majors, capacities and strengths of each civil servant. Review the age structure of planning civil servants, rejuvenate the planning age contingent, and structure to increase the proportion of planned female cadres. In order to build and develop a contingent of civil servants with sufficient qualities, capacities and qualifications to meet the requirements of the industrialization and modernization of the country and the socio-economic development requirements of the province, of the district. In the coming years, Dien Bien district needs to focus on researching, building and perfecting the civil servant structure system in a reasonable manner, on the basis of determining job positions, standard civil servant titles and other factors. district characteristics, especially the ethnic composition structure of civil servants to develop the planning, recruitment, employment and management plans of public servants; elaborate planning and plans for training and retraining the contingent of civil servants, including short-term and long-term training, to ensure sustainable development and well implement the ethnic policies of the Party and State.

\subsection{Solutions to Manage, Use and Arrange Civil Servants}

It is necessary to develop and perfect the regulations on the assessment of staff in a scientific and appropriate manner. On the basis of staff assessment, staff standards, implementation of staff work contents such as leadership planning, management, rotation for training, retraining and challenges; select, arrange, use staff, ensure principles, transparency, openness, fairness and objectivity.

Strengthening and improving the quality of training and retraining; The training and retraining must be according to the planning and associated with the use; renovating contents, programs and methods of training and retraining, focusing on improving administrative skills, skills in handling and problem solving for cadres and civil servants.

Renewing the assessment of cadres and civil servants; the assessment must ensure that the prescribed content and process are public and democratic with clear and transparent standards; Associate the assessment with the arrangement, use, appointment, training, retraining, rewarding, discipline and implementation of policies for cadres and civil servants.

Strengthen management work and continue to improve discipline, administrative discipline, public service ethics, professional ethics of cadres and civil servants.

\subsection{Strengthening the Training and Retraining of Civil Servants}

Planning and training plans for training and retraining civil servants, including short-term and 
long-term classes in the country and in the province, must be close to the requirements of each specialized agency to meet development requirements. and timely supplementing the young, highly qualified civil servants who have been properly trained for the district agencies, which lack the leading core civil servants, excellent experts in the fields.

Must strengthen the state management of training and retraining of civil servants; for district training institutions such as the political fostering center, it is necessary to reform fundamentally, comprehensively, synchronously, with a system of training and retraining for civil servants; linking the training and fostering in theory with practical skills. There must be a combination of theory and practice, between training and fostering basic professional knowledge with legal knowledge, administrative skills, communication skills, and situation handling skills. professional skills of office, information technology, foreign languages, indigenous languages with the update of new knowledge, between traditional and modern methods by many modes and many levels to meet the requirements in public service activities and public service execution.

In order for the training and retraining of civil servants to be effective, annually, the District People's Committee needs to evaluate the performance of civil servants after training and retraining, and promptly revise the experience to organize and sending civil servants to attend the next training and retraining courses; to prioritize the allocation of reasonable funds to support and create conditions for civil servants sent to study to study with peace of mind.

With the characteristics of a district with over $90 \%$ of the population being ethnic minorities, the District People's Committee needs to make the ethnic language training program one of the mandatory requirements for civil servants of specialized agencies. It is part of the district People's Committee to facilitate communication and behavior between civil servants and people in public service execution, and at the same time encourage civil servants to participate in foreign language training courses to be able to communicate when working with foreign organizations and individuals.

\subsection{Increase Motivational Measures for Civil Servants}

In the coming years, the District People's Committee needs to strengthen the direction, inspection and supervision of specialized agencies under the District People's Committee in the full implementation of all regimes and remuneration policies for civil servants according to the regulations. current state regulations, especially the implementation of salary policies and allowances and allowances based on wages, on the other hand through the implementation of state policies and treatment for civil servants that discover unreasonable points in the policy and remuneration, especially the salary policy to propose to the State to amend and supplement to suit the requirements and tasks of the period of accelerating industrialization and modernization. and international integration, so that the salary of civil servants is really the main source of income to support the civil servants and their children, really become the driving force in building and improving the quality of the public workforce. function in state administrative agencies. Implement well the policy of emulation and commendation, promptly commend and reward civil servants with outstanding achievements in public service, ensuring that the commendation of collectives and individuals is done in a 
manner. publicity, transparency, right people, right achievements.

Ensuring the assignment of jobs in accordance with the capabilities, capabilities and strengths of civil servants: When civil servants are assigned jobs in accordance with their abilities and strengths, they will maximize their working capacity in the most normal conditions. Therefore, organizations need to rely on the psychological characteristics and personalities of civil servants to arrange jobs accordingly.

Clearly defining the goals to be achieved of each individual civil servant: Clearly defining the job goals for each individual civil servant is extremely important, because when there are clear goals, civil servants will have motivation. and aim to strive, actively seek to achieve that goal. However, if the target is too high or too low, it is only superficial to be performed, it will cause the public servant to become depressed and lose the motivation to work.

Creating promotion opportunities for civil servants: Any individual wants to have progress in his career. Promotion is a practical need of the people working in the state administrative agencies, because they create opportunities for personal development, increase their status, prestige and power.

\section{Conclusion}

Improving the management of civil servants is one of the major issues, related to many levels and branches from central to local and must be implemented for many years. Therefore, it is necessary to have special attention of the Government, the Ministry of Home Affairs, relevant ministries and branches, all levels, and branches of Dien Bien province and also the responsibility of the leaders of the district People's Committee, members of the district People's Committee, each official working in departments, committees, and specialized agencies of the district People's Committee, in which it is necessary to create strong support from the society and the people.

\section{References}

Diem, P. (2012). Institutions on civil servants in Vietnam. Retrieved from http://vietnamlawmagazine.vn/institutions-on-civil-servants-in-vietnam-4478.html

Dieu, N. (2007). About Vietnam's tool regime. National political publishing house (Vn.).

Government. (2010). Regulations who are civil servants. Descree No. 06/2010/NĐ-CP 25/01/2010 (Vn.).

Government. (2010). Training and restraining of civil servants. Decree No. 18/2010/NĐ-CP ngày $5 / 3 / 2010(\mathrm{Vn}$.).

Government. (2010). Regulations on recruitment, employment and management of civil servants. Decree No. 24/2010/NĐ-CP 15/3/2010 (Vn.).

Government. (2011). State administrative reform master program for the period 2011-2020. Resolution No. 30c/NQ-CP 08/11/ 2011(Vn.).

Hang, P. (2013). Experiences in civil servant management by job positions of countries in the 
world and applying to Vietnam. Ministry level scientific research topic (Vn.).

Huong, N. \& Loi, N. (2018). Curriculum for public administration. Hanoi, financial publishing house $(\mathrm{Vn}$.).

Itzhak G. \& Jennifer O. (2015). International Encyclopedia of the Social \& Behavioral Sciences (Second Edition). Retrieved from https://www.sciencedirect.com/topics/social-sciences/civil-servants

Long, N. (2020). The new policy applies to cadres, civil servants and public employees. Retrieved from https://www.quanlynhanuoc.vn/2020/01/27/chinh-sach-moi-ap-dung-voi-can-bo-cong-chuc-v ien-chuc/

Ministry of Finance - Ministry of Interior. (2014). Regarding the regime of autonomy and self-responsibility for the use of administrative management funds for state agencies. Joint Circular No. 71/2014/TTLT-BTC-BNV 30/5/2014(Vn.).

Ngoc, D. (2019). Some issues regarding the contingent of cadres and civil servants (Last part). $\quad$ Retrieved from http://hdll.vn/vi/nghien-cuu---trao-doi/mot-so-van-de-ve-doi-ngu-can-bo-cong-chuc-phan-cu oi.html

Party Central Committee, Session VIII (1997). Staff strategy of the period of accelerating industrialization and

modernization of the country. Resolution No.03-NQ/TW 18/6/1997(Vn.).

Party Central Committee. (2007). Promoting administrative reform, improving the effectiveness and efficiency of the management of the state apparatus. Resolution no 17-NQ/TW 01/8/2007 (Vn.).

PJ ACAD. (2020). Role of civil services in a democracy. Retrieved from https://timesofindia.indiatimes.com/readersblog/pracin-jain-academy/role-of-civil-services-in -a-democracy-28544/

Politburo. (2004). Regarding the work of leadership and management planning in the period of accelerating national industrialization and modernization. Resolution No. 42-NQ/TW 30/11/2004 (Vn.).

Prime Minister. (2003). Regulations on appointment, re-appointment, rotation, resignation, and dismissal of leading cadres and civil servants. Decision No. 27/2003/QĐ-TTg 19/02/2003(Vn.).

Tan, L. (2018). Ongoing reformation of the civil service in Vietnam. Retrieved from https://vietnamlawmagazine.vn/ongoing-reform-of-the-civil-service-in-vietnam-6108.html

Thang, T. (2018). Management and usage cadres, civil servants and public employees according to Ho Chi Minh's ideology, morality and style. Retrieved from https://tcnn.vn/news/detail/41583/Quan-ly-su-dung-can-bocong-chuc-vien-chuc-theo-tu-tuon 
g-dao-duc-phong-cach-Ho-Chi-Minh.html

Trung, N. (2018). Staff management: Current situation and solutions. Retrieved from https://tcnn.vn/news/detail/39784/Cong_tac_quan_ly_can_bo_Thuc_trang_va_giai_phapall.ht $\mathrm{ml}$

Vietnamese Congress. (2008). Law on cadres, civil servants no. 22/2008/QH12 (Vn.).

\section{Copyright Disclaimer}

Copyright for this article is retained by the author(s), with first publication rights granted to the journal.

This is an open-access article distributed under the terms and conditions of the Creative Commons Attribution license (http://creativecommons.org/licenses/by/4.0/). 